\title{
Adipogenic Differentiation of Mesenchymal Stem Cell Derived from Bone Marrow of Sprague Dawely Rats
}

\author{
M.M. Sobh ${ }^{\mathrm{a}^{*}}$, M.O. El-Emam ${ }^{\mathrm{b}}$, I.H. El-Sayed ${ }^{\mathrm{c}}$, M.M. Mashaly $^{\mathrm{b}}$, M.A. Sobh ${ }^{\mathrm{a}}$ \\ ${ }^{a}$ Urology and Nephrology Center, Mansoura, Egypt \\ ${ }^{b}$ Chemistry Deptment, Faculty of Science, Damietta University, Egypt \\ ${ }^{c}$ Genetic Engineering and Biotechnology Institute, Minufiya University, Egypt
}

Received: 25 August 2013 / Accepted: 10 October 2013

*Corresponding author (Tel: +20.1018821557; email: manona_87@hotmail.com)

\begin{abstract}
Stem cells are classes of undifferentiated cells that are able to differentiate into specialized cell types. The present study investigates the mechanism and regulation of differentiation from bone marrow mesenchymal stem cells (MSCs) into adipose cell line. MSCs were isolated from bone marrow of adult Sprague Dawely rats. Cells were cultured in MSCs expansion medium, for 2-3 weeks. The colony forming unit assay and immunophenotyping were performed. The cells were cultured in adipogenic differentiation medium for 21 days and their differentiation were determined by oil red staining and controlling the expression of peroxisome proliferation-activated receptor $\gamma(\mathrm{PPAR} \gamma)$, lipoprotein lipase (LPL), leptin and adiponectin genes.

After 1 week of MSCs growth in culture, the cells showed small spindle-shaped fibroblastoid feature. Also, the flowcytometric assay showed higher expression of Cluster of Differentiation (CD)29 followed by CD90 and CD44. In addition, the adipogenic differentiation was apparent after 1 week of incubation. Moreover, RT-PCR revealed that the cells express PPAR $\gamma$, lipoprotein lipase (LPL), leptin and adiponectin.
\end{abstract}

Keywords: Adipogenesis, Adiponectin, Immunophenotyping, Leptin, Lipoprotein Lipase, Mesenchymal stem cells, Peroxisome Proliferation-Activated Receptor $\gamma$

\section{Introduction}

Mesenchymal stem cells (MSCs) are nonhematopoietic cells, typically isolated from the stromal fraction of adult bone marrow [1]. Murine MSCs are classically obtained from the femurs and tibias of rat [2]. After their initial isolation from human and rat, MSCs have since been successfully harvested from many other specie [3]. They have also been isolated from tissues [4].
After placing whole bone marrow cells in plastic culture dishes with medium supplemented with $10 \%$ fetal calf serum, Friedenstein et al. [5] demonstrated that bone marrow contains hematopoietic non-adherent cells (HSCs) along with a rare population of plastic-adherent cells (MSCs).After a few days, these adherent cells, of heterogeneous appearance, start to proliferate. The initial clones of adherent cells expanded into round-shaped colonies composed of fibroblastoid 
cells, thus the term of Colony Forming Unitfibroblasts (CFU-f) [6].

In order to facilitate studying MSC biology, there are three criteria needed to identify MSCs: 1) Plastic adherence, 2) Expression of cluster of differentiation (CD) markers, Rat bone marrowMSCs express of cell-surface markers such as CD29, CD44, CD90 and CD106, and rBM-MSCs were -ve for CD45, CD34 [7], and 3) Capacity to differentiate into osteocytes, adipocytes and chondrocytes [8].

In vitro, adipogenesis can be induced by treating MSCs with dexamethasone, isobutyl methyl xanthine (IBMX) and indomethacin [9]. The differentiation might be confirmed using oilred staining technique and controlling the expression of specific proteins [1].

\section{Materials and methods}

\section{Harvesting and Culturing of MSC}

Adult inbred male Sprague Dawley (SD) rats that weighing 180 to $210 \mathrm{~g}$ were served as bone marrow donors. Bone marrow was obtained from the femurs and tibia of adult SD rats [5]. Rat bone marrow cells were cultured in basic media (Dulbecco's modified Eagle's medium (DMEM), Sigma Chemical Comp. St. Louis, MO, USA) containing $10 \%$ fetal bovine serum (FBS, Sigma). The cells were then cultured in DMEM containing $10 \% \mathrm{FBS}$, penicillin $\left(100 \mathrm{U} \mathrm{ml}^{-1}\right)$ and streptomycin $\left(100 \quad \mu \mathrm{g} \mathrm{ml} \mathrm{m}^{-1}\right)$ at $37^{\circ} \mathrm{C}$ in a humidified atmosphere that contained 5\% CO2.MSC was detached with trypsin/EDTA, used for experiments after the $3^{\text {rd }}$ passage.

Flow cytometry for cell surface antigen expressions

The identification of adherent cells was performed by flow cytometric analysis according to the previously reported method [10]. The immunophenotyping was performed on EPICSXL flow cytometry (Coulter, Miami, Fl). The cells were analyzed with the most appropriate gate using the combination of forward and side scatters.

\section{Adipogenesis assay}

The $3^{\text {rd }}$ passage cells were treated for 3 weeks with adipogenic differentiation medium (DMEM-
LG, $10 \mathrm{ml} \mathrm{l}^{-1}$ FBS, $1 \mu \mathrm{mol} \mathrm{l}^{-1}$ dexamethasone, 10 $\mu \mathrm{g} \mathrm{ml}^{-1}$ bovine insulin, $0.5 \mathrm{mmol} \mathrm{l}^{-1} 1$-methyl-3IBMX and $100 \mu \mathrm{mol} \mathrm{l}^{-1}$ indomethacin). Lipid accumulation was detected by: 1) oil O Red staining 2) RT-PCR analysis of adipocytic markers expression, RNA extractions were performed with QIAamp RNA Blood Mini kit (Qiagen). Reverse transcriptions of cDNAs was done using QuantiTect Reverse Transcription Kit (Qiagen). cDNAs was then amplified using, Leptin:

5'TTCACACACGCAGTCGGTATC3' (sense)

5'GTGAAGCCCGGGAATGAAG3' (antisense),

LPL:

5'GTACAGTCTTGGAGCCCATGC3' (sense) 5'GCCAGTAATTCTATTGACCTTCTTGTT3'

(antisense),

PPAR $\gamma:$

5'CATACATAAAGTCCTTCCCGCTG3'

(sense)

\section{5'TTGTCTGTTGTCTTTCCTGTCAAGA3' (antisense)}

Adiponectin:

5'GGGATTACTGCAACCGAAGG3' (sense)

5'CCATCCAACCTGCACAAGTTT3'

(antisense),

PCR reactions were carried out in $8 \mu$ mole $1^{-1}$ Fermentas* PCR Master Mix, 2x, $6 \mu$ mole $1^{-1}$ primers, $2 \mu$ mole per 1 cDNAs in a thermal cycler: one cycle at $95^{\circ} \mathrm{C}$ for $5 \mathrm{~min}$, followed by 35 cycles at $95^{\circ} \mathrm{C}$ for $1 \mathrm{~min}, 58^{\circ} \mathrm{C}$ for $45 \mathrm{sec}$, and $72^{\circ} \mathrm{C}$ for $35 \mathrm{sec}$, and then final extension at $72^{\circ} \mathrm{C}$ for $5 \mathrm{~min}$.

\section{Results}

Harvest and Culture of MSC

MSCs were generated and grown for at least 2 passages in culture. Contaminating HSCs were depleted during passage 1 and MSCs were 
morphologically defined by a fibroblast-like appearance under an inverse microscopy.

\section{Fibroblast-Like Colony-Forming Unit Assay}

MSCs after isolation from bone marrow were characteristic by their adherence to plastic and were able to form fibroblast like colonies. The photomicrographs of rat bone marrow mesenchymal stem cell (MSCs) after one week of culture showed that, these cells grew in colonies that contained heterogeneous small spindleshaped fibroblastoid cells and these cells were more rounded.
Flow cytometry for cell surface expression assay

The immunophenotypes of MSCs surface markers obtained from 5 groups of bone marrow donor rats was tested by flow cytometric analysis using CD90, CD29, CD45, CD34, CD44 surface markers.

As in Table 1 and Fig. 1, the frequency of the presence of CD29 was the highest (97.6\%) which is followed by that of CD90 (96.3\%) and that of CD44 (94.5\%). A lower frequency were found for CD45 (1.7\%) and for CD34 (0.28\%).

Table 1: Immunophenotyping of MSCs surface markers

\begin{tabular}{llllll}
\hline Test & CD29 & CD44 & CD90 & CD45 & CD34 \\
\hline 1 & 98.3 & 93.7 & 96.7 & 1.97 & 0.2 \\
2 & 96.6 & 95.3 & 97.3 & 1.38 & 0.3 \\
3 & 96.7 & 94.6 & 95.4 & 1.56 & 0.4 \\
4 & 98.5 & 94.8 & 96.2 & 1.88 & 0.2 \\
5 & 97.8 & 93.9 & 95.8 & 1.73 & 0.3 \\
Mean \pm SD & $97.6 \pm 0.9$ & $94.5 \pm 0.7$ & $96.3 \pm 0.7$ & $1.7 \pm 0.2$ & $0.28 \pm 0.1$ \\
\hline
\end{tabular}

1, Flow cytometry analysis test $1 ; 2$, test; 3 , test $3 ; 4$, test $4 ; 5$, test5

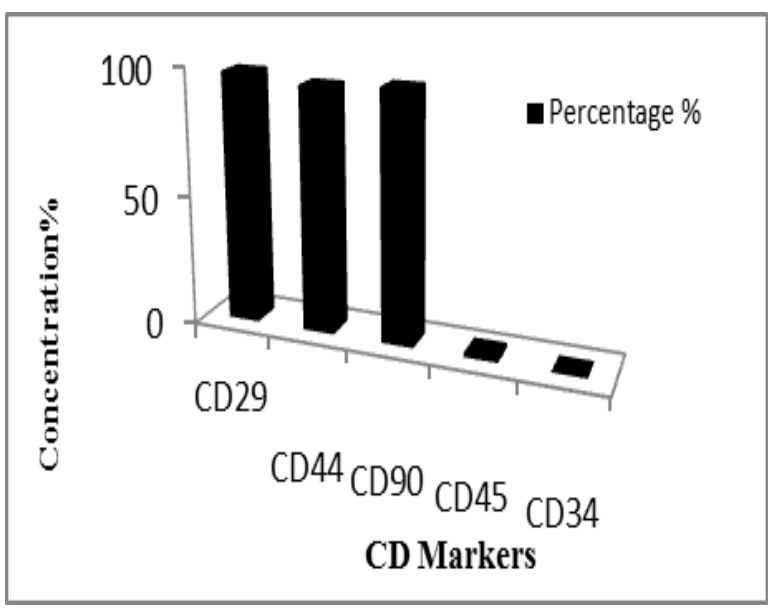

Fig. 1 Immunophenotyping of Mesenchymal Stem Cells (MSCs) surface markers

\section{Adipogenic assay}

Adipogenic differentiation was apparent after 1 week of incubation with adipogenic induction medium. Between the culture periods of $3 \pm 2$ weeks, almost all cells contained numerous Oil Red O-positive lipid droplets. Photomicrographs of MSCs showing differentiative potential. Adipocyte differentiation is visualized by highly refractive intracellular lipid vacuoles and droplets appear as cherry red spheres within the cells and by Oil Red O staining.

\section{Reverse transcription polymerase chain reaction}

Differentiation was further demonstrated by RTPCR analysis of adipocytic markers expression. Rat MSCs in basic culture conditions expressed A) Lipoprotein Lipase B) Adiponectin C) Leptin and a transcription factor known to be involved in control of adipocytic differentiation D) PPAR$\gamma$ at different time intervals, after 4 days, 7 days 14 days and 21 days .After staining gel by ethidioum bromide then visualized by translmrater and photographed by gel decumention system.

\section{Discussion}

As mentioned before in literature murine MSCs were obtained from the femurs and tibias of rat 
[2]. The present study demonstrated that after placing whole bone marrow cells in plastic culture dishes with medium bone marrow contains hematopoietic non-adherent cells (HSCs) along with a rare population of plasticadherent cells (MSCs). After a few days, the adherent cells, of heterogeneous appearance, start to proliferate. The initial clones of adherent cells expanded into round-shaped colonies composed of fibroblastoid cells, thus the term of Colony Forming Unit-fibroblasts (CFU-f). These results are consistent with those reported in many studies $[6,2]$.

The next point in the current study was to investigate cell-surface markers. Our data reported that all cultured cells expressed positive mesenchymal CD29, CD44 and CD90 and were negative for CD45 and CD34 surface marker these findings are in agreement with other studies including those of Macedo et al. [7] and Dominici et al. [8].

The last point in this study was to examine the in vitro, adipogenesis induced by treating MSCs with a hormonal cocktail containing dexamethasone, IBMX and indomethacin. The differentiation was confirmed by using oil-red staining technique. Also, this study further demonstrated that these morphologically adipocyte cells can express specific genes for adipocyte lipid-binding protein; our results confirmed the findings of $[1,9]$. The results of this study not only established the condition under which the MSCs can be adipogenically differentiated but also optimized such differentiation.

\section{Acknowledgement}

This work was supported by the aid of:

1. Dr. Layla M. Tharwat Abdel Hadi Abdou Saleh, Assistance Lecture of Clinical pathology and chemistry, Faculty of Medicine, Mansoura University, Egypt.

2. Dr. Doaa Mahmoud Al-Ghanam, Supervisor of Blood Bank, the University Hospital, Mansoura, Egypt.

\section{References}

[1] M.F. Pittenger, A.M. Mackay, S.C. Beck, R.K. Jaiswal, R. Douglas, J.D. Mosca, Multilineage potential of adult human mesenchymal stem cells. Science 284 (1999) 143-147

[2] D.P. Lennon, A.I. Caplan, Isolation of rat marrow-derived mesenchymal stem cells. Exp. Hematol. 34 (2006) 1606-1607

[3] G.V. Silva, S. Litovsky, J.A. Assad, A.L. Sousa, B.J. Martin, D. Vela, S.C. Coulter, J. Lin, J. Ober, W.K. Vaughn, R.V. Branco, E.M. Oliveira, R. He, Y.J. Geng, J.T. Willerson, E.C. Perin, Mesenchymal stem cells differentiate into an endothelial phenotype, enhance vascular density, and improve heart function in a canine chronic ischemia model. Circulation 111 (2005) 150-156

[4] Y. Amoh, L. Li, R. Campillo, K. Kawahara, K. Katsuoka, S. Penman, R.M. Hoffman, Implanted hair follicle stem cells form Schwann cells that support repair of severed peripheral nerves. Proc. Natl. Acad. Sci. USA 102 (2005) 17734-17738

[5] A.J. Friedenstein, R.K. Chailakhjan, K.S. Lalykina, The development of fibroblast colonies in monolayer cultures of guinea-pig Bone marrow and spleen cells. Cell Tissue Kinet. 3 (1970) 393-403

[6] A.I. Caplan, Mesenchymal stem cells. J Orthop. Res. 9 (1991) 641-650

[7] L.M. De Macedo Braga, S. Lacchini, B.D. Schaan, B. Rodrigues, K. Rosa, K. De Angelis, L.F. Borges, M.C. Irigoyen, N.B. Nardi, In situ delivery of bone marrow cells and mesenchymal stem cells improves cardiovascular function in hypertensive rats submitted to myocardial infarction. J. Biomed. Sci. 15 (2008) 365-374

[8] M. Dominici, K. Le Blanc, I. Mueller, I. SlaperCortenbach, F. Marini, D. Krause, R. Deans, A. Keating, D.J. Prockop, E. Horwitz, Minimal criteria for defining multipotent mesenchymal stromal cells. The International Society for Cellular Therapy position statement. Cytotherapy 8 (2006) 315-317

[9] J.E. Dennis, P. Charbord, Origin and differentiation of human and murine stroma. Stem Cells 20 (2002) 205-214

[10] M. Ayatollahi, M. Kabir Salmani, M. Soleimani, B. Geramizadeh, M.H. Sanati, M. Gardaneh, S.Z. Tabei, Expansion of human marrow derived mesenchymal stem cells and their transdifferentiation potential. IRCMJ 12 (2010) $446-452$ 
الملخص العربى

التحول الدهني للخلايا الجزعيه الوسطيه المستخلصه من نخاع عظام الجرذان البيضاء

محمد أحمد صبح', منه الله أسامه صدقي الإمام²، إبراهيم حلمي السيد33، محمد محمد مشالي²، محمد عبد القادر صبحي 1

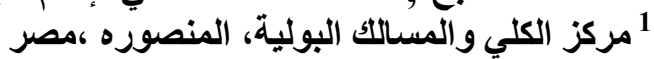

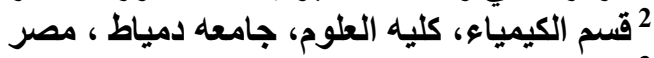
3 معهد الهندسه الوراثيه وليه التكنوملوجيا الحيوياط،، جامعه المنوفيه، مصر

الخلايا الجزعيه هي فئه من الخلايا الغيرمتمايزه والتي لها القدرة علي التمايز إلي أنواع الخدلايا

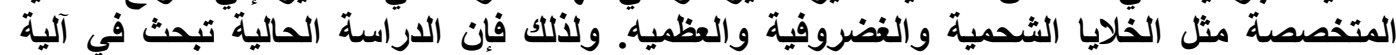

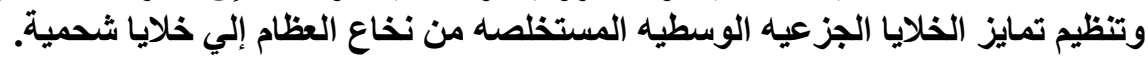

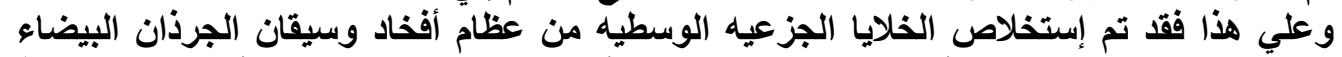

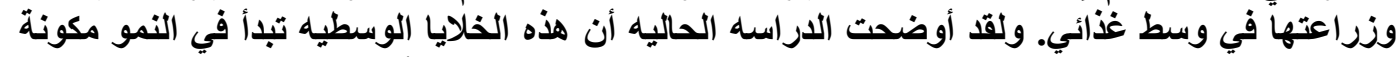

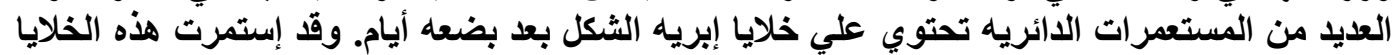

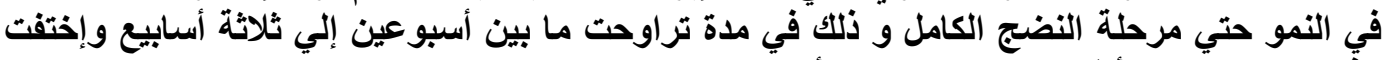

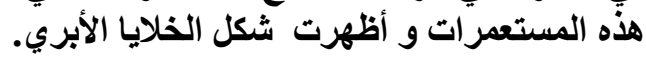

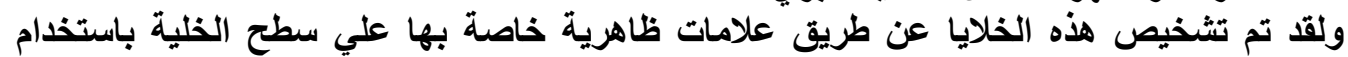

التذفق الخلوي. و لقد بينت الدراسة الحالية أن هذه الخلايا الوسطية أعطت نتيجة إيجابية مع

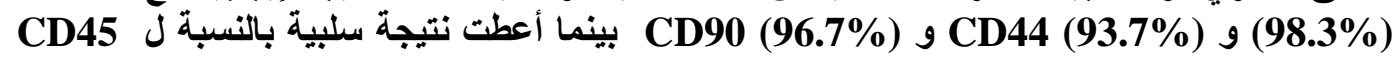
CD34 (علامات سطح الخلية).

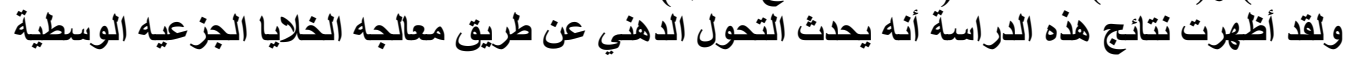

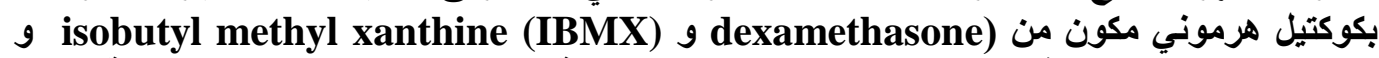
إئخدomethacin

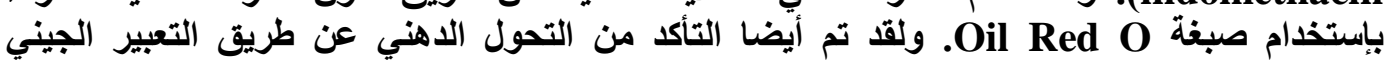

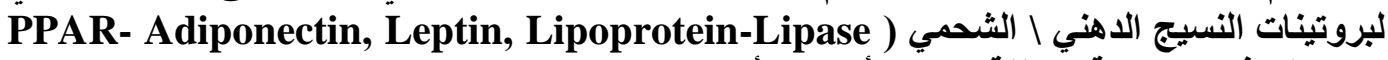

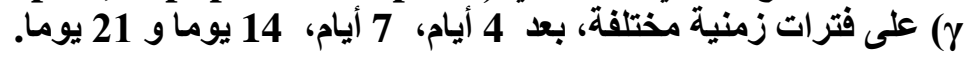

